\title{
Determination of conjugated linoleic acid isomers by liquid chromatography and photodiode array detection*
}

\author{
M. Czauderna, J. Kowalczyk, I. Wąsowska and K.M. Niedźwiedzka
}

\author{
The Kielanowski Institute of Animal Physiology and Nutrition, \\ Polish Academy of Sciences \\ 05-110 Jabłonna, Poland
}

(Received 10 February 2003; accepted 4 April 2003)

\begin{abstract}
In the current paper we describe the development of our method for quantification of underivatized individual conjugated linoleic acid (CLA) isomers by silver ion liquid chromatography ( $\mathrm{Ag}^{+}$-HPLC). Positional and geometric CLA isomers were separated on two commercially available Chrompac (The Netherlands) ChromSpher $5 \mu \mathrm{m}$ Lipids columns $(250 \times 4.6 \mathrm{~mm})$ protected by a guard column $(10 \times 3 \mathrm{~mm})$ containing the same stationary phase. Lyophilized skeletal muscle, adipose tissue, liver, brain and pancreas samples were hydrolyzed with $2 \mathrm{M} \mathrm{NaOH}$ at $80-85^{\circ} \mathrm{C}$ for $30-35 \mathrm{~min}$ in sealed tubes. After cooling, the hydrolyzates were acidified with $4 \mathrm{M} \mathrm{HCl}$ and the free CLA isomers were extracted with dichloromethane. The organic solvent was removed in a stream of argon and then the residue was re-dissolved in dichloromethane followed by injection of the resulting solution (10-30 $\mu 1)$ onto the HPLC columns (column temperature: $25^{\circ} \mathrm{C}$ ). A mobile phase of $1.6 \%$ acetic acid and $0.0125 \%$ acetonitrile in $n$-hexane was chosen as the optimum mobile phase for fractionation of the individual CLA isomers. Analyses of underivatized isomers were performed by the isocratic elution program (flow-rate of $1 \mathrm{ml} / \mathrm{min}$ ) and UV detection at $234 \mathrm{~nm}$. All positional and geometric CLA isomers in standards and biological samples were efficiently retained on the columns and were satisfactorily separated from all endogenous species present in biological materials in about $55 \mathrm{~min}$. The first low intensity peak group was trans-trans CLA isomers (23-27 min), the second highest intensity peak group was cis-trans/trans-cis isomers (31-38 min), while the last group was low intensity cis-cis isomers (41-52 min). The use of two silver ion-exchange columns with direct UV detection offers low limits of detection (0.14-1.02 $\left.\mathrm{ngl}^{-1}\right)$, quantification $\left(0.42-3.06 \mathrm{ngl}^{-1}\right)$ and satisfactory "purity" of analytical peaks, so, this simple $\mathrm{Ag}^{+}$-HPLC method can be used for routine analysis of CLA isomer biodistribution in the body of animals.
\end{abstract}

KEY WORDS: conjugated linoleic acid, isomers, determination, HPLC

\footnotetext{
* Supported by the State Committee for Scientific Research, Grant No. 3 P06Z 03422
} 


\section{INTRODUCTION}

Conjugated linoleic acid (CLA) is a mixture of positional and geometric isomers of linoleic acid, which is found preferentially in ruminant meats and dairy products. CLA has received considerable attention due to its numerous physiological effects including anti-obesity activity (Sebedio et al., 1997; Bauman et al., 1999; Pariza et al., 2001; Evans et al., 2002; Turpeinen et al., 2002). It has been known that feeding CLA resulted in reduction in white adipose tissue weights and serum triacylglycerol levels in obese/diabetic model rats (Azain et al., 2000; Blankson et al., 2000; Thom et al., 2001). These effects may be attributed to both enhanced beta-oxidation of fatty acids and reduced triacylglycerol synthesis in adipose tissue and liver in the animal model. However, it is becoming increasingly clear that the biological activity of CLA isomers is dependent on the position of the double bonds. Theoretically, a number of CLA isomers is possible. These isomers differ in the position and configuration of the double bond pairs. Presently, we know of seventeen CLA isomers, however, the major isomer in a CLA mixture is the cis-9,trans-11 isomer which represents from 80 to $95 \%$ of the total CLA isomer mixture. Many studies have implicated the cis-9,trans-11 isomer as the physiologically most active (Santora et al., 2000). In fact, research with animals has demonstrated that this isomer is able to enhance immune functions (i.e. increased antibody formation), possesses anti-carcinogenic properties and reduces mammary tumors when butter containing a high concentration of CLA is fed (Devery et al., 2001; Pariza et al., 2001). Under certain dietary conditions, such as high-concentrate or low- fibre diets, the CLA profile could be altered so the concentration of another isomer, trans-10,cis-12, increased in milk fat. This isomer caused reduced milk fat synthesis (lactations), decreased food intake and body fat accretion (growth) (Park et al., 1999; Azain et al., 2000; Santora et al., 2000; Thom et al., 2001; Alasnier et al., 2002). Indeed, it was recently shown that the trans-10,cis-12 isomer decreased $\Delta 9$-desaturation activity and inhibited steaoryl-CoA desaturase mRNA expression (Gnäding et al., 2001; Evans et al., 2002).

As mentioned above, the predominant natural CLA isomer in humans and animals is the cis-9,trans-11 isomer, the trans-10, cis-12 isomer represents several percent of a total CLA mixture, while other CLA isomers (cis/cis, trans/cis or trans/trans) with double bonds mainly in positions 8,10 or 11,13 , are only a minor constituent of the CLA pool, none the less, to investigate their role in living organisms an efficient method of separation and quantification is needed. For this reason, we decided to develop a simple, specific and highly efficient HPLC method in which CLA isomers are determined without derivatization (i.e. directly). The use of liquid chromatography with direct photodiode array detection for determination of free CLA isomers in biological materials has received wide attention due to its 
satisfactory accuracy and sensitivity. Moreover, there is the possibility that the "purity" of all analytical peaks may be assessed by examining the UV spectra of assayed species in standards and biological materials (Czauderna et al., 2002). Underivatized CLA isomers and their methyl esters have been separated by an ion-exchange column loaded with silver ions and monitored by refractive index or, more sensitively, by low-wavelength UV detection (Kramer et al., 1997; Momchilova et al., 1998; Cross et al., 2000). Indeed, silver ion chromatography is a method that utilizes a property of silver ions that form polar complexes reversibly with unsaturated centers of fatty acids (FAs), while the residual silanol groups of the ChromSpher Lipids columns produce interactions with the carboxylic acid groups of FAs. Consequently, CLA isomers are efficiently retained on these columns. Therefore, the object of the current study was to find a more versatile silver ion chromatography method ( $\left.\mathrm{Ag}^{+}-\mathrm{HPLC}\right)$ with UV detection for highly efficient fractionation of underivatized free CLA isomers in various types of biological materials.

\section{MATERIAL AND METHODS}

\section{Reagents}

HPLC-grade n-hexane (95\%) and acetonitrile were purchased from LabScan (Dublin, Ireland), while acetic acid and dichloromethane were obtained from POCh Gliwice (Poland). Conjugated linoleic acid (CLA) isomer mixture (standard 1) was obtained from Sigma (St. Louis, MO, USA); cis-9,trans-11 and trans-10,cis-12 CLA isomers and a CLA isomer mixture (standard 2) were supplied by Larodan Fine Chemicals AB (Malmö, Sweden).

\section{HPLC configuration}

A Waters (Milford, MA USA) HPLC 625LC system was used. The system comprised a 515 pump, a 712 WISP autosampler, a 996 photodiode array detector (DAD) and a 2487 dual $\lambda$ absorbance detector. DAD was operated in a UV range from 195 to $400 \mathrm{~nm}$ with a spectral resolution of $1.2 \mathrm{~nm}$ and a measurement frequency of 1 spectrum per sec. Development of the HPLC method, collection and data analyses were performed using Millennium 2001 software (version 2.15) and a Pentium III computer (Compaq). Analytical ion-exchange columns loaded with silver ions used were two 250 x $4.6 \mathrm{~mm}$ Chrompac ChromSpher 5 $\mu \mathrm{m}$ Lipids columns (The Netherlands) in conjunction with a guard column of 10 x $3 \mathrm{~mm}$ containing the same stationary phase. The ambient temperature was 22$24^{\circ} \mathrm{C}$, while a column heater maintained the temperature at $25^{\circ} \mathrm{C}$. Minimum tubing 
diameter and distance was used between the autosampler injector and detectors. The $\mathrm{Ag}^{+}$-HPLC system pressure was $4.78 \pm 0.03 \mathrm{MPa}$.

\section{Analytical mobile phases and isocratic elution system}

The isoctratic system was operated at $25^{\circ} \mathrm{C}$ with a flow-rate of $1 \mathrm{ml} / \mathrm{min}$ and an in-line degasser (Waters). The eluent for the isocratic elution was prepared from n-hexane-acetic acid-acetonitrile $(98.4: 1.6: 0.0125 \mathrm{v} / \mathrm{v} / \mathrm{v})$. The reproducibility of the fractionation was sensitive to a small fluctuation in the concentration of acetic acid and more so to the concentration of acetonitrile. Thus, the mobile phase was carefully stirred before use. The columns were equilibrated with the freshly prepared mobile phase at least $40 \mathrm{~min}$ before sample injection.

The limits of detection $\left(\mathrm{L}_{\mathrm{D}}\right)$ were defined as a signal-to-noise ratio of three, while the limits of quantification $\left(\mathrm{L}_{\mathrm{Q}}\right)$ were determined as 10 times the noise level (Gratzfeld-Husgen and Schuster, 1996; Meyer, 1999). The noise level under the analytical peak was calculated from the baseline from the left and right sides of the analytical peak.

\section{Preparation and hydrolysis of samples}

Skeletal muscle, adipose tissue, liver, brain and pancreas samples were collected from rats fed a standard diet enriched $(1-2 \%, w / w)$ with the CLA isomer mixture (Larodan). All samples were frozen, lyophilized and the obtained residues were stored in sealed tubes at $-20^{\circ} \mathrm{C}$ until analyzed. Muscle $(\sim 45 \mathrm{mg})$, adipose tissue $(\sim 25 \mathrm{mg})$, liver $(\sim 20 \mathrm{mg})$, brain $(\sim 50 \mathrm{mg})$ and pancreas $(\sim 20 \mathrm{mg})$ samples were hydrolyzed with $3.5-4.0 \mathrm{ml}$ of $2 \mathrm{M} \mathrm{NaOH}$ at $80-85^{\circ} \mathrm{C}$ for $30-35$ $\mathrm{min}$ in sealed tubes. Solutions obtained after hydrolysis should be protected from light and stored in sealed tubes under argon. After cooling the hydrolysates were acidified with $4 \mathrm{M} \mathrm{HCl}$ to $\mathrm{pH} \sim 2$ and free fatty acids were extracted four times with $3.5 \mathrm{ml}$ of dichloromethane. The lower organic layer (i.e. dichloromethane) was dried with $\mathrm{Na}_{2} \mathrm{SO}_{4}(50-100 \mathrm{mg})$ and then the organic solvent was removed under a gentle stream of argon (Czauderna and Kowalczyk, 2001). Afterwards the residue was re-dissolved in $1 \mathrm{ml}$ of dichloromethane and then $20-30 \mu 1$ of the resulting solution were injected on to the HPLC columns.

\section{RESULTS AND DISCUSSION}

Separation of a CLA isomer mixture from biological materials was carried out using two silver ion-exchange columns connected in series. As expected, this $\mathrm{Ag}^{+}$- HPLC mode showed satisfactory separation of geometric and positional 
isomer mixtures into three groups related to trans-trans, cis-trans or trans-cis and cis-cis configurations. In fact, this liquid chromatography method allows better fractionation of positional CLA isomers within each geometrical group (Figure 1A) compared with gas chromatography techniques and reversed-phase $\mathrm{C}_{18}$ HPLC methods (Gutnikov 1995; Banni et al., 1996; Kramer et al., 1997; Sebedio et al., 1997; Santora et al., 2000; Czauderna and Kowalczyk, 2001, 2002; Alasnier et al., 2002). For various types of assayed biological materials it is necessary to use optimum chromatographic elution conditions. Therefore, an isocratic elution system composed of acetic acid (1.6\%) and acetonitrile $(0.0125 \%)$ in n-hexane, a flow-rate of $1 \mathrm{ml} / \mathrm{min}$ (column temperature: $25^{\circ} \mathrm{C}$ ), and UV detection in the spectral range of 225-260 nm were found to provide excellent baseline stability. What is particularly puzzling, however, is that only n-hexane purchased from Lab-Scan ensured very small baseline noise and substantial retention of all assayed CLA isomers on silver-columns. On the other hand, n-hexane (95\%, HPLC grade) from Sigma (USA) also provided good baseline stability, however, all CLA isomers eluted faster. Unfortunately, n-hexane obtained form J.T. Baker (The Netherlands) ( $95 \%$ HPLC grade) could not be used as the main component of the mobile phase because of a high of baseline noise (i.e. near \pm 0.05 of the absorbance unit for UV detection at $234 \mathrm{~nm}$ ).

In order to improve the method's accuracy and specificity, selective UV detection at $234 \mathrm{~nm}$ together with photodiode array monitoring (from 190-300 $\mathrm{nm}$ ) was used. Underivatized CLA isomers, like other conjugated diens, had high molar absorptivity at $\sim 234 \mathrm{~nm}$ because of the presence of a chromophore group (i.e. double bonds separated by a single carbon-carbon bond-conjugated unsaturated). Thus, the high molar absorptivity and the close proximity of the absorbance maximum to $234 \mathrm{~nm}$ make free CLA isomers almost ideally suited for the highly efficient $\mathrm{Ag}^{+}$-HPLC separation with direct UV detection. Indeed, all components of the mobile phase are transparent in this UV range (i.e. near $234 \mathrm{~nm}$ ) as well as other endogenous species in processed biological samples have a relatively low molar absorptivity compared with conjugated unsaturated compounds. As expected, all CLA isomer peaks were absent from the blank when the isocratic $\mathrm{Ag}^{+}$-HPLC system was used. As can be seen from Figure 1A, excellent peak shapes, close to symmetrical, were observed even with elution times from 20 to $55 \mathrm{~min}$. The introduction of larger amounts of acetic acid (from 1.7 to $2.5 \%$ ) to the mobile phase (n-hexane) reduced the duration of a total HPLC run (from 50 to $20 \mathrm{~min}$ ), however, loss of resolution of the major and minor isomers was observed. On the other hand, decreasing the acetic acid concentration in the mobile phase (from 1.4 to $0.3 \%$ ) significantly increased the duration of HPLC analyses, so, the last CLA isomer peaks appeared at around 60 and $270 \mathrm{~min}$, respectively. An attempt was also made to evaluate the effect of variations of the acetonitrile content in the mobile phase on the resolution of the CLA isomers. As 

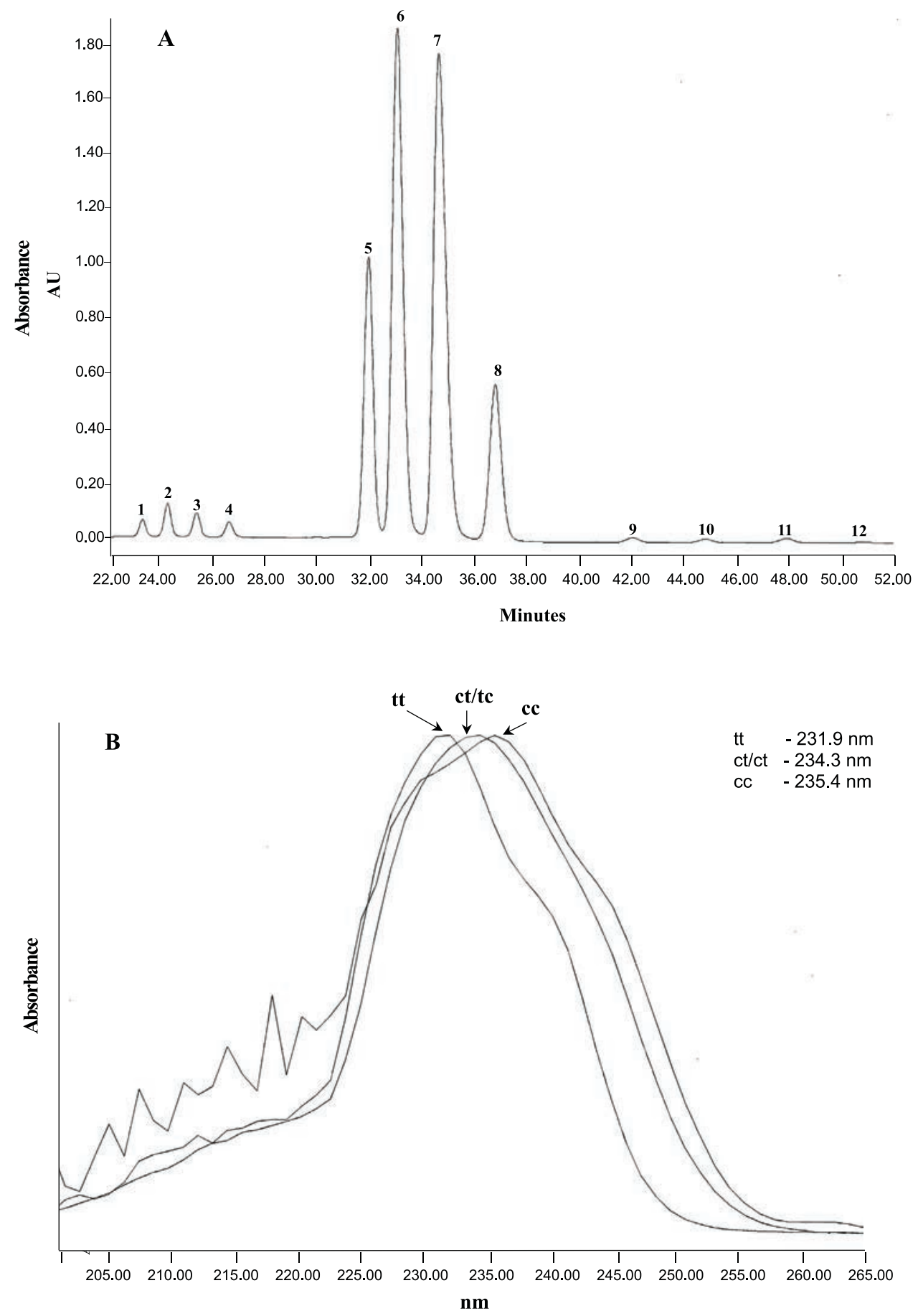


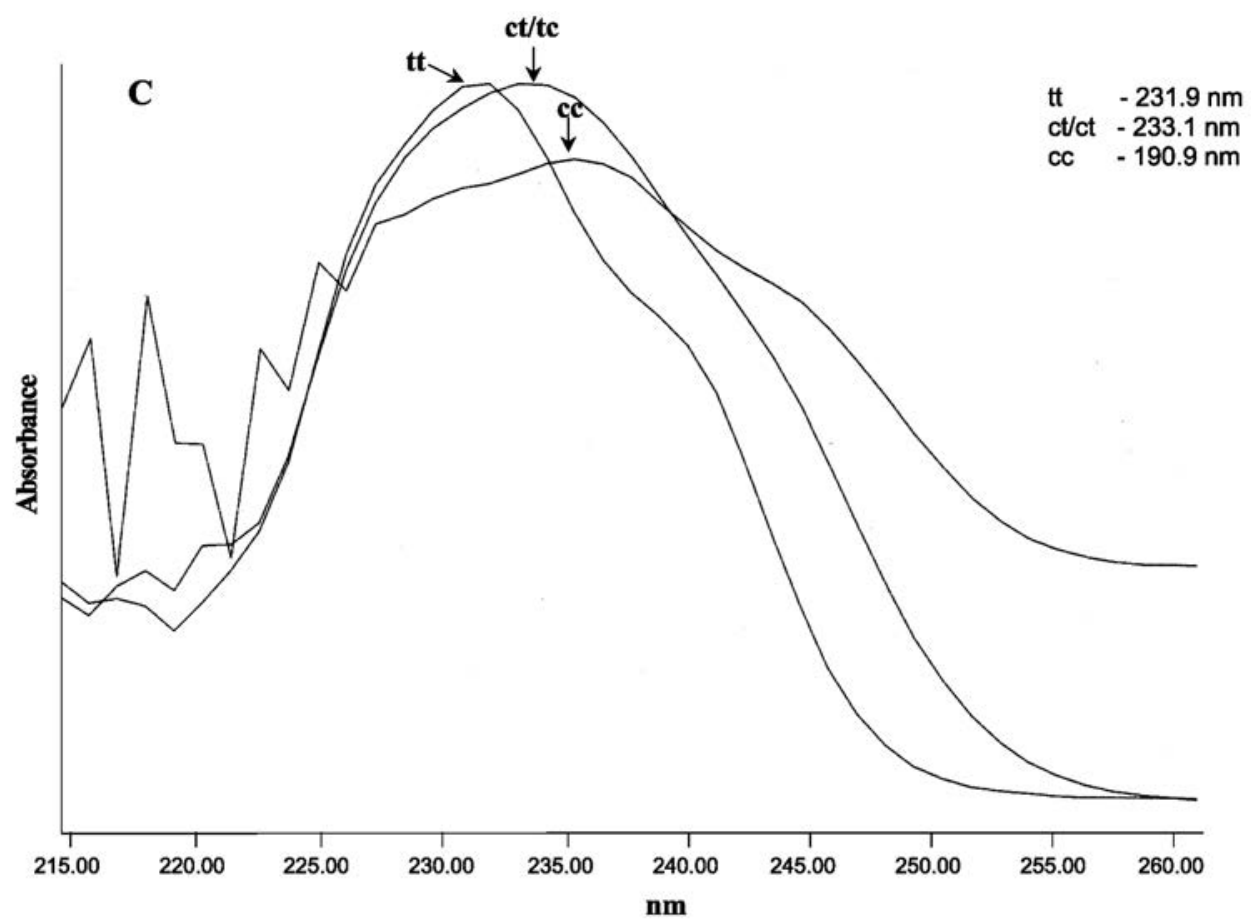

Figure 1. Part of typical optimised silver ion chromatogram for (A) a standard CLA isomers mixture (LARODAN) obtained at $1.0 \mathrm{ml} / \mathrm{min}$ (the columns temperature: $25^{\circ} \mathrm{C}$ ). The underiva- tized free isomers eluted by $1.6 \%$ acetic acid (AA) and $0.0125 \%$ acetonitrile $(\mathrm{ACN})$ in $n$-hexane. The individual isomers are: 1 , trans-11,trans-13; 2, trans-10,trans-12; 3, trans-9,trans-11; 4, trans-8,trans-10 (the first minor peaks group); 5, cis-11,trans-13/trans-11,cis-13; 6, cis-10,trans-12/trans-10, cis-12; 7, cis-9,trans-11/trans-9,cis-11; 8, cis-8,trans-10/trans-8,cis-10 (the second large peaks group); 9, cis-11,cis-13; 10, cis-10,cis-12; 11, cis-9,cis-11; 12, cis-8, cis-10 (the third minor peaks group). UV absorbance spectra (B) of groups of the geometric CLA isomers: trans-trans (tt), cis-trans/trans-cis (ct/tc) and cis-cis (cc). The tt, $\mathrm{ct} / \mathrm{tc}$ and $\mathrm{cc}$ isomers showed the average absorbance maximum at 231.9, 233.1 and $235.4 \mathrm{~nm}$, respectively. B - for the CLA isomers mixture (Larodan standard), C - for processed liver sample (rats fed the standard died enriched with CLA isomers mixture, $2 \% \mathrm{w} / \mathrm{w}$ )

expected, the increase of the acetonitrile concentration (from 0.0125 to $0.025 \%$ ) resulted in reduction of the duration of the total HPLC analysis (i.e. 55 and $45 \mathrm{~min}$, respectively). Detailed analysis of HPLC chromatograms revealed that the mobile phase containing more than $5 \%$ acetonitrile produced a large signal with very slightly resolved major cis/trans and trans/cis CLA isomers, while more than $10 \%$ acetonitrile in the mobile phase generally failed to achieve any separation (i.e. the mobile phase pumped at $1 \mathrm{ml} / \mathrm{min}$ produced a single large peak for the four major CLA components). It is evident from the chromatographic runs that acetonitrile is more efficient than acetic acid with respect to reduction of the resolution quality of 
the CLA isomers. Interestingly, with the flow-rate reduced from 1.5 to $1.0 \mathrm{ml} / \mathrm{min}$, improvement of the resolution of all isomers was achieved. The reproducibility of profiles and retention times of CLA isomers was very sensitive to small changes in solubility of processed samples. This may have been related to the low solubility of evaporated hydrolysate of assayed samples, especially adipose tissues, in n-hexane, acetonitrile or methanol. Therefore, it is recommended to re-dissolve all processed samples in dichloromethane (see section Preparation and hydrolysis of samples). As can be seen from a chromatographic run of a CLA standard (Larodan) (Figure 1A), our chromatographic mode of choice allows highly discerning separation of all positional and geometric isomers into three well-separated groups of isomers: the first peak group (from 23 to $27 \mathrm{~min}$ ) was the low intensity trans-trans isomers (the minor component in the CLA mixture), the central group (from 31 to $38 \mathrm{~min}$ ) was the highest intensity cis-trans/trans-cis isomers (the main isomers in the CLA mixture), while the last peak group (from 41 to $52 \mathrm{~min}$ ) was the small intensity cis-cis isomers (the minor isomers in CLA pool). Obviously, within each group, there was further separation into positional isomers. Indeed, the retention times of individual isomers increased with decreasing value of the sum of the position numbers of unsaturated bonds in the CLA isomer. We found that the current isocratic elution mode eluted the principal CLA isomers: cis-9,trans-11 and trans-10, cis-12 at $35.0 \pm 0.3$ and $33.8 \pm 0.3 \mathrm{~min}$, respectively. Detailed analysis of chromatograms revealed that, also, practically identical resolution and a similar profile of the CLA isomers was obtained using a CLA mixture purchased from Sigma. Interestingly, as can be seen from UV spectra, the absorption spectra of trans-trans, cis-trans/trans-cis and cis-cis CLA isomers bear a close resemblance (see Figure 1B), however, the absorbance maximum is slightly dependent upon the geometric form of assayed isomer (i.e. near at 231.9, 233.1 and $235.4 \mathrm{~nm}$, respectively). Considering the above results, the use of a photodiode array detector to identify the geometric configuration of the CLA isomers can be recommended (compare Figure 1B and 1C).

Subsequently, our new $\mathrm{Ag}^{+}$-HPLC system was applied for quantification CLA isomers in muscle, adipose tissue, liver, pancreas and brain samples. Fortunately, as the current HPLC method was applied to these biological materials, satisfactory baseline stability and excellent resolution of all CLA isomers were also obtained. Obviously, the all CLA isomers were identified by the retention time of standards injected separately and by the recovery estimation carried out by addition of the CLA isomer standard to assayed biological materials. Furthermore, the identification the CLA isomers was proved by comparing UV spectra (from 195 to $400 \mathrm{~nm}$ ) of the CLA isomers in standards and in examined biological samples. The values of the correlation coefficient practically equal one and good linearity of the response of the UV detector to the amount of CLA isomers injected onto HPLC columns evidenced that the current $\mathrm{Ag}^{+}-\mathrm{HPLC}$ method with direct 
monitoring at $234 \mathrm{~nm}$ provided the appropriate analytical tool for determination of CLA isomers in the concentration range from the limit of quantification to 2.6 $\mathrm{mg} / \mathrm{ml}$. Moreover, the low values of the limit of detection $\left(\mathrm{L}_{\mathrm{D}}\right)$ and the limit of quantification $\left(\mathrm{L}_{\mathrm{Q}}\right)$ for the CLA isomers point to satisfactory sensitivity of the current HPLC procedure (Table 1). It seems clear from $\mathrm{L}_{\mathrm{D}}$ and $\mathrm{L}_{\mathrm{Q}}$ values that our $\mathrm{Ag}^{+}$-HPLC method offers better sensitivity compared with the previously reversed-phase $\mathrm{C}_{18}$-HPLC methods with pre-column derivatization (Czauderna and Kowalczyk, 2001, 2002). The current $\mathrm{Ag}^{+}$-HPLC procedure gives satisfactory sensitivity and precision permitting appropriate detection and quantification of individual CLA isomers in tissues and organs of monogastric animals fed a standard diet enriched with the CLA isomers $(\sim 1 \%$, w/w). Obviously, our silverion chromatography offers satisfactory sensitivity and precision for the routine analysis of the individual CLA isomers in milk, intestinal digesta, muscles and organs of ruminants fed a standard diet (Czauderna et al., 2003).

TABLE 1

Limits of detection $\left(\mathrm{L}_{\mathrm{D}}\right)$ and limits of quantification $\left(\mathrm{L}_{\mathrm{Q}}\right)$ derived from determination of the underivatized CLA isomers (the UV detection at $234 \mathrm{~nm}$ )

\begin{tabular}{|c|c|c|}
\hline $\begin{array}{l}\text { CLA } \\
\text { isomers }^{\mathrm{a}}\end{array}$ & 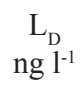 & $\begin{array}{c}\mathrm{L}_{\mathrm{O}} \\
\mathrm{ng} \mathrm{l}^{-1}\end{array}$ \\
\hline trans -11 ,trans -13 & 0.36 & 1.08 \\
\hline trans -10, trans -12 & 0.15 & 0.44 \\
\hline trans -9, trans -11 & 0.14 & 0.42 \\
\hline trans- 8 , trans- 10 & 0.46 & 1.39 \\
\hline cis-11,trans-13/trans-11,cis-13 ${ }^{\mathrm{b}}$ & 0.86 & 2.58 \\
\hline cis-10,trans-12/trans-10,cis-12 & 0.55 & 1.65 \\
\hline cis-9,trans-11/trans-9,cis-11 & 0.48 & 1.44 \\
\hline cis-8,trans-10/trans-8,cis-10 & 0.95 & 2.81 \\
\hline cis- $11, c i s-13$ & 0.78 & 2.34 \\
\hline cis-10,cis-12 & 0.68 & 2.05 \\
\hline cis-9,cis-11 & 0.77 & 2.31 \\
\hline cis- $8, c i s-10$ & 1.02 & 3.06 \\
\hline
\end{tabular}

${ }^{a}$ see Figure $1 \mathrm{~A}$

${ }^{b}$ the sum of the unresolved geometric CLA isomers

\section{Reliability of the $\mathrm{Ag}^{+}-H P L C$ method}

Reliability and reproducibility of the $\mathrm{Ag}^{+}$-HPLC method were assessed by performing replicate injections of various amounts of CLA. As can be seen from chromatographic runs of the CLA standards (Sigma and Larodan) and muscle samples, the regression approach was satisfactory, i.e. the correlation coefficients (r) for the individual CLA isomers determined in the assayed samples were very close to one (from 0.997 to 1.000 ). 


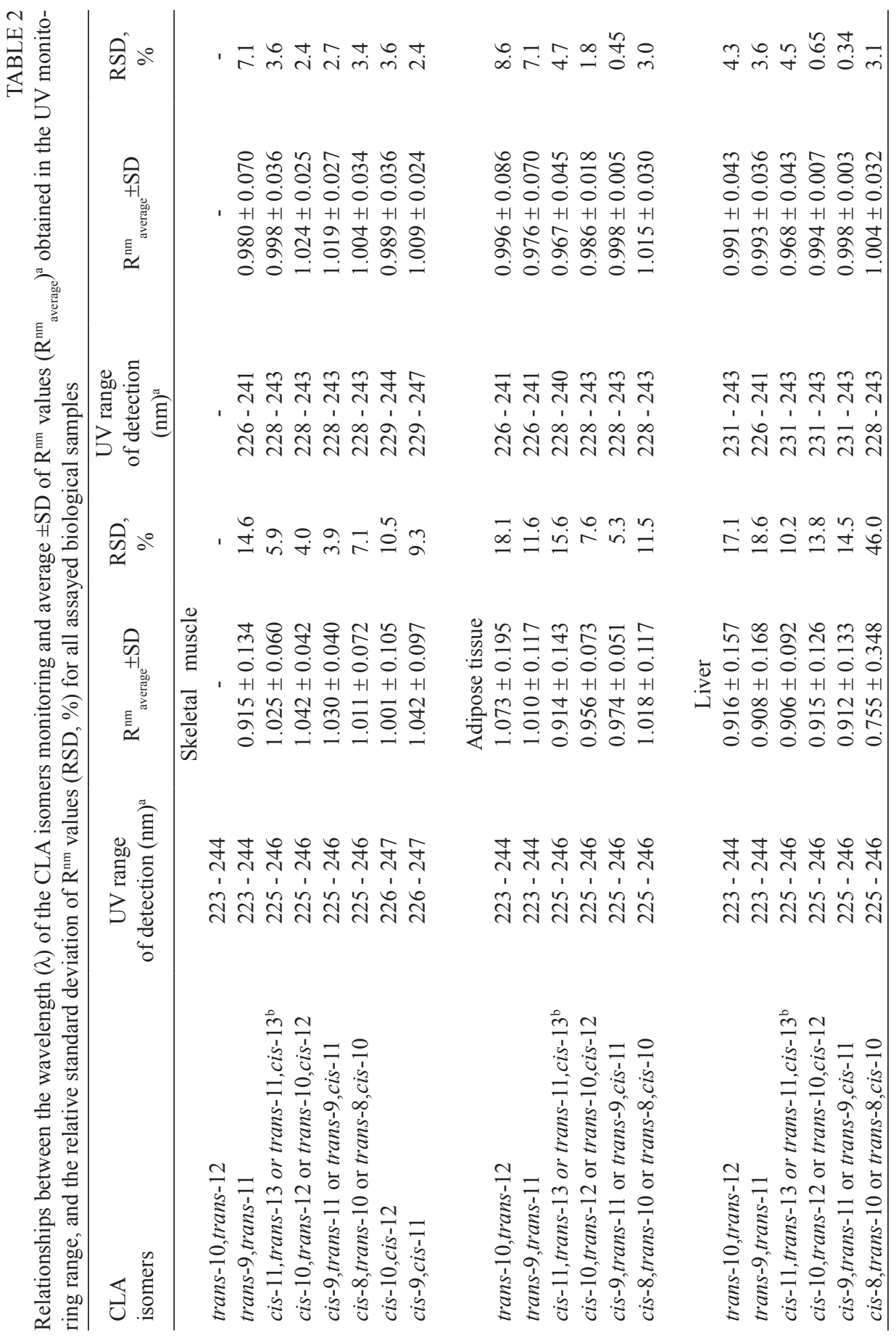




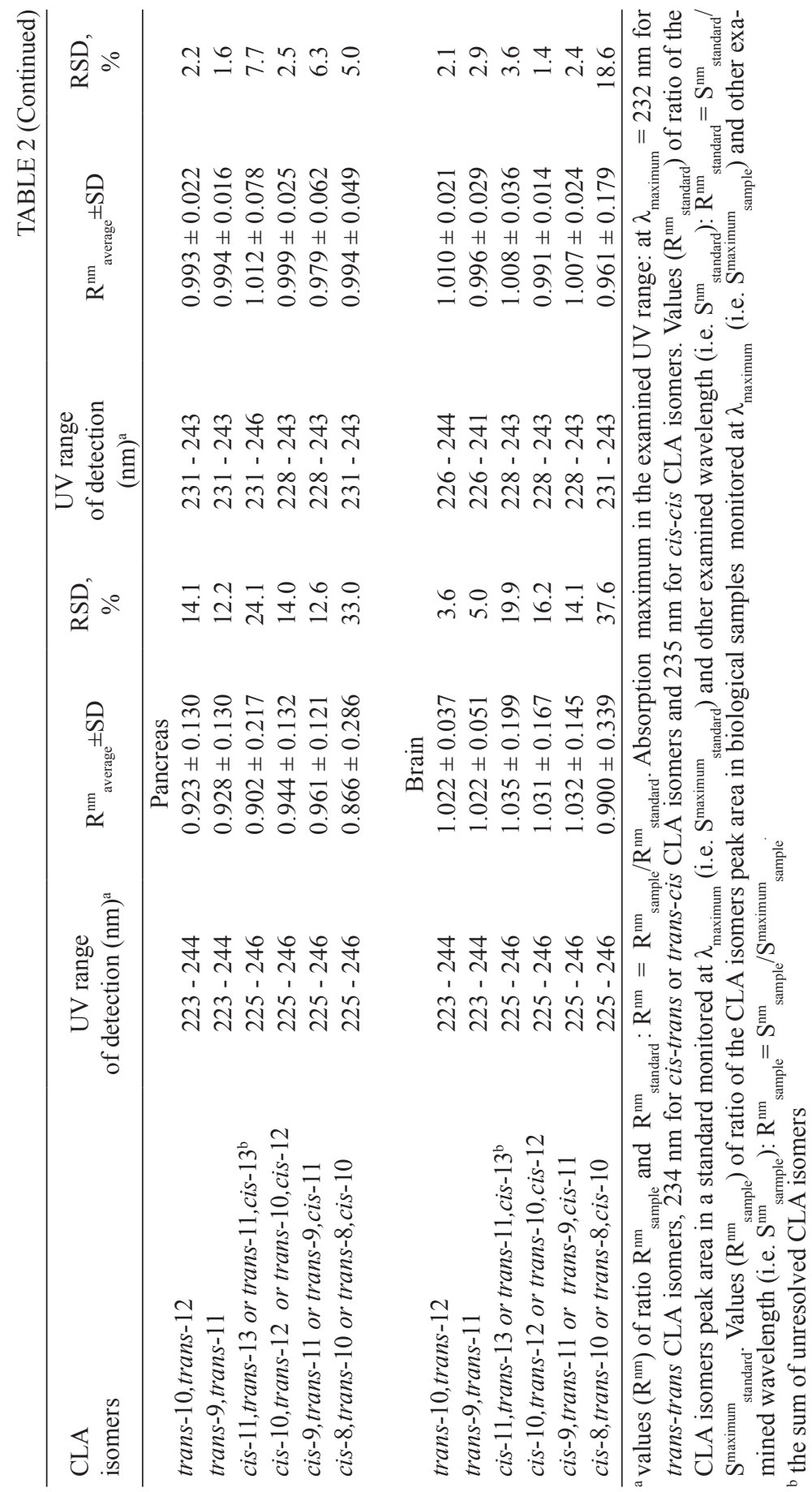


The accuracy of the method was further assessed by determining relationships between the monitoring wavelength $\left(\lambda_{\mathrm{nm}}\right)$ and the ratio $\left(\mathrm{R}^{\mathrm{nm}}\right)$ of the peak area of the CLA isomers in all processed biological samples $\left(\mathrm{R}_{\text {sample }}^{\mathrm{nm}}\right)$ and a calibration standard $\left(\mathrm{R}_{\text {standard }}^{\mathrm{nm}}\right.$ ) (i.e. $\mathrm{R}^{\mathrm{nm}}=\mathrm{R}^{\mathrm{nm}}{ }_{\text {sample }} / \mathrm{R}^{\mathrm{nm}}$ standard ; for abbreviations see Table 2) (Czauderna and Kowalczyk, 2001). It is evident from the obtained results that all values of $\mathrm{R}^{\mathrm{nm}}$ average were practically equal to 1 , as well as values of the relative standard deviation (RSD) were relatively small, however, always satisfactory accuracy was obtained when the CLA isomer detection was based on UV monitoring at longer wavelengths and/or a narrower UV range (i.e. generally in the spectral range from 228 to $240 \mathrm{~nm}$ ). Comparison of results (Table 2) indicates that peaks corresponding to isomers were assumed to be more "pure" in the narrower UV range due to the better integration precision of the examined peaks. In fact, as can be seen from the UV spectra (Figures 1B and 1C) the CLA isomers showed a very high absorption band in the spectral range from 228 to 240 $\mathrm{nm}$. Therefore, the UV detector set beyond this UV range was found to produce a smaller response, moreover, direct measurements at the shorter UV range $(\lambda<228$ $\mathrm{nm}$ ) are less selective for the CLA isomers in the presence of endogenous species in all processed biological samples. Consequently, the most accurate and precise determination of the CLA isomers was offered by UV detection in the vicinity of the absorbance maximum and in the longer the spectral range (i.e. to $240 \mathrm{~nm}$ ).

\section{CONCLUSIONS}

The current chromatographic method allows precise, accurate and specific determination of conjugated unsaturated fatty acids using a typical UV detector set at $234 \mathrm{~nm}$. This monitoring at $234 \mathrm{~nm}$ is a fortunate compromise between "satisfactory purity" of analytical peaks, a relatively high absorbance of assayed conjugated isomers, and relatively low absorbance of endogenous interfering species present in biological materials. Elimination of special clean-up procedures makes our $\mathrm{Ag}^{+}$-HPLC method a very simple, and therefore less expensive and time-consuming, analytical tool suitable for routine determination of conjugated isomers in large numbers of biological samples. Our HPLC method was found to be more sensitive, selective and versatile than previously published chromatographic methods (Banni et al., 1996; Cross et al., 2000; Czauderna and Kowalczyk, 2001, 2002; Czauderna et al., 2002). Indeed, two long, high-resolution $\mathrm{Ag}^{+}$columns and diode array detection enabled satisfactory fractionation and discrimination of the geometric and positional CLA isomers in various types of biological materials. Consequently, the current HPLC system can be a possible alternative method in important nutritional and physiological research. 


\section{REFERENCES}

Alasnier C., Berdeaux O., Chardigny J-M., Sebedio J-L., 2002. Fatty acid composition and conjugated linoleic acid isomers given as triacylglycerols. J. Nutr. Biochem. 13, 337-345

Azain M., Hausman D., Sisk M., Flatt W., 2000. Dietary conjugated linoleic acid reduces rat adipose tissue cell size rather than cell number. J. Nutr. 130, 1548-1554

Banni S., Carta G., Contini M.S., Angioni E., Delana M., Dessi M.A., Melis M.P., Corongiu F.P., 1996. Characterization of conjugated diene fatty acids in milk, dairy products, and lamb tissues. J. Nutr. Biochem. 7, 150-155

Bauman D.E., Baumgard L.H., Corl B.A., Griinari J.M., 1999. Biosynthesis of conjugated linoleic acid in ruminants. Proceedings of the American Society o Animal Science, pp. 1-15

Blankson H., Stakkestad J., Fagertun H., Thorm E., Wadstein J., Gudmundsen O., 2000. Conjugated linoleic acid reduces body fat mass in overweight and obese humans. J. Nutr. 130, 2943-2948

Cross R.F., Ostrowska E., Muralitharan M., Dunshea F.R., 2000. Mixed mode retention and the use of competing acid for the $\mathrm{Ag}^{+}$-HPLC analysis of underivatized conjugated linoleic acids. J. High. Resol. Chromatogr. 23, 317-323

Czauderna M., Kowalczyk J., 2001. Separation of some mono-, di- and triunsaturated fatty acids containing 18 carbon atoms by HPLC and photodiode detection. J. Chromatogr. B 760, 165-178

Czauderna M., Kowalczyk J., 2002. HPLC separation of some unsaturated and saturated fatty acids. Chem. Anal. 47, 867-882

Czauderna M., Kowalczyk J., Niedźwiedzka K.M., Wąsowska I., 2002. Determination of free and protein primary amino acids in biological materials by high-performance liquid chromatography and photodiode array detection. J. Anim. Feed Sci. 11, 143-167

Czauderna M., Kowalczyk J., Podkański A., Szumacher-Strabel M., 2002. Determination of conjugated fatty acid in ovine, milk, meat, fat and intestinal digesta. Ars Separatoria Acta 1, 1-7

Czauderna M., Kowalczyk J., Wąsowska I., Niedźwiedzka K.M., Newbold J., 2003. Determination of free isomers of conjugated linoleic acid in biological samples by liquid chromatography. Proceedings of the XXVII Symposium on Chromatographic Methods of Organic Compounds Separation. Silesia University, Katowice (Poland), (in press)

Devery R., Miller A., Stanton C., 2001. Conjugated linoleic acid and oxidative behaviour in cancer cells. Biochem. Soc. Trans. 29, 341-344

Evans M.E., Brown J.M., McIntosh M.K., 2002. Isomer-specific effects of conjugated linoleic acids (CLA) on adiposity and lipid metabolism. J. Nutr. Biochem. 13, 508-516

Gnäding S., Rickert R., Sébédio J.L., Steinhart H., 2001. Conjugated linoleic acid (CLA): physiological effects and production. Eur. J. Lipid Sci. Technol. 103, 56-61

Gratzfeld-Husgen A., Schuster R., 1996. HPLC for Food Analysis. Hewllett-Packard (Germany), p. 117

Gutnikov G., 1995. Fatty acid profiles of lipid samples. J. Chromatogr. B 671, 71-89

Kramer J.K.G., Fellner V., Dugan M.E.R., Sauer F.D., Mossoba M.M., Yurawecz M.P., 1997. Evaluating acid and base catalysts in the methylation of milk and rumen fatty acids with special emphasis on conjugated dienes and total trans fatty acids. Lipids 32, 1219-1228.

Meyer V.R., 1999. Practical High-Performance Liquid Chromatography. Wiley. Chichester (UK), p. 78

Momchilova Sv., Nikolova-Damyanova B., Christie W.W., 1998. Silver ion high-per-formance liquid chromatography of isomeric cis- and trans-octadecenoic acids. Effect of the ester moiety and mobile phase composition. J. Chromatogr. A 793, 275-282

Pariza M., Park Y., Cook M., 2001. The biologically active isomers of conjugated linoleic acid. Prog. Lipid Res. 40, 283-298 
Park Y., Storkson J.M., Albright K.J., Liu W., Pariza M.W., 1999. Evidence that the trans-10, cis12 isomer of conjugated linoleic acid induced body composition changes in mice. Lipids 34, 235-241

Santora J.E., Palmquist D.L., Roehrig K.L., 2000. Trans-vaccenic acid is desaturated to conjugated linoleic acid in mice. J. Nutr. 130, 208-215

Sebedio J.L., Juaneda P., Dobson G., Ramilison I., Martin J.C., Chardigny J.M., Christie W.W., 1997. Metabolites of conjugated isomers of linoleic acid (CLA) in the rat. Biochim. Biophys. Acta $1082,275-284$

Thom E., Wadstein J., Gudmundsen O., 2001. Conjugated linoleic acid reduced body fat in healthy body fat in healthy, exercising humans. J. Int. Med. Res. 29, 392-396

Turpeinen A.M., Mutanen M., Aro A., Salminen I., Basu S., Palmquist D.L., Griinari J.M., 2002. Bioconversion of vaccenic acid to conjugated linoleic acid in humans. Amer. J. Clin. Nutr. 76, 504-510

\section{STRESZCZENIE}

\section{Oznaczanie izomerów sprzężonego kwasu linolowego metodą chromatografii cieczowej z de- tekcją fotodiodową}

Opisano ulepszoną metodę bezpośredniego oznaczania izomerów kwasu linolowego (CLA) wykorzystując jonowo $\left(\mathrm{Ag}^{+}\right)$-wymienną chromatografię cieczową. Pozycyjne i geometryczne izomery CLA rozdzielano na dwóch komercyjnych kolumnach (ChromSpher 5 m Lipids; 250 x 4,6 mm) zabezpieczonych kolumną ochronną (10 x $3 \mathrm{~mm}$ ). Zliofilizowane próbki tkanki mięśniowej, tkanki thuszczowej, wątroby, mózgu i trzustki hydrolizowano w $2 \mathrm{M} \mathrm{NaOH}$ w temperaturze $80-85^{\circ} \mathrm{C}$ przez $30-35$ min. Po zakwaszeniu hydrolizatów $4 \mathrm{M} \mathrm{HCl}$ wolne izomery CLA ekstrahowano chlorkiem metylenu. Wolne izomery CLA oznaczano bezpośrednio stosując izokratyczną elucję (temperatura kolumn: $25^{\circ} \mathrm{C}$ ) oraz UV detekcję przy $234 \mathrm{~nm}$. Fazę ruchomą stanowił roztwór kwasu octowego $(1,6 \%)$ oraz acetonitrylu $(0.0125 \%) \mathrm{w}$ n-heksanie. Chromatograficzna analiza mieszaniny geometrycznych i pozycyjnych izomerów CLA w standardach i próbach biologicznych pozwoliła na uzyskanie dobrze rozdzielonych izomerów, które tworzyły trzy dobrze rozdzielone grupy pików - pierwsza grupa małych pików: trans-trans izomery (23-27 min), druga grupa dużych pików: cis-trans/trans-cis (31-38 min) izomery oraz trzecia grupa małych pików: cis-cis izomery (41-52 min). Stosując detekcję UV przy długości fali $234 \mathrm{~nm}$ uzyskano niskie wartości granicy detekcji jakościowej $\left(0,14-1,02 \mathrm{ngl}^{-1}\right) \mathrm{i}$ ilościowej $\left(0,42-3,06 \mathrm{ngl}^{-1}\right)$ dla analizowanych izomerów. Wysoka czułość metody, „czystość” analitycznych pików oraz zadowalająca jej dokładność, precyzja i prostota sprawia, że prezentowana procedura może być rutynowo stosowana $\mathrm{w}$ badaniach nad biodystrybucją CLA izomerów w tkankach zwierzęcych. 